If the tail of the comet consisted of a fine dust not in a state of incundescence reflecting or dispersing the sun's rays, we should expect its light to be completely polarised. We seem, therefore, driven to assume, either, $r$, that the tail consists of fine incandescent particles; or, 2, of particles whose diameter is not small compared with the wavelength; or, 3, of incandescent gas; or, 4 , possibly of all three of these states combined.

A. CoWper Ranyard

\section{Photographic Irradiation}

IN a letter to NATURE, vol. ix, p. I83, I gave a short description of some experiments on photographic irradiation. The conciusion to which these experiments pointed was that there is a kind of photographic irradiation, caused either by the bright light producing an intense state of chemical activity, which has the power of extending itself in every direction; or what seems more probable, the parts of the collodion on which the bright light is falling become luminous and reflect light to the surrounding parts of the sensitive film, and thus extend the chemical change on each side of the true optical boundary line. As the subject is at present under discussion, I send you the results of the following experiments, which seem to support the above conclusion. In a darkened room a vertical opening 18 in. by 5 in. was made in the shutter; over the opening was fixed a piece of paper thick enough to stop most of the light, and only allow as much to pass as world give a decided but not deep photographic impression. Three long, narrow, parallel openings were cut in the paper, one opening was left clear to the sky, the next was covered with one thickness of tissue paper, and the third with two thicknesses of tissue paper. There was thus produced three parallel bars of different brightness on a uniform and darker ground. Sensitive wet plates were prepared in the usual way on glass and opaque black plates; across the front of the plates, and almost in contact with the col lodion, was fixed a horizontal bar of thin blackened metal in such a position that it would cross the image of the luminous bars in the camera. The photographs, after exposure, were developed in the ustal way, and it was found that the shadow cast by the horizontal opaque bar was not bounded by straight lines, but the ends of all the bright bars projected into the shadow, and the brighter the bar the farther it projected. I had no means of measuring accurately the bar and its shadow, but there seems but little doubt that the bright bars extended underneath the opaque bar, whilst the edge of the darker ground at the side of the bright bars gave the correct line of the shadow. Now this extension of the bright bars could not have been caused by the refection from the back of the plate, as this result was always got whether glass or opaque black plates were used. Nor could it have been caused by the oblique pencils referred to by Lord Lindsay and Mr. A. C. Ranyard, because, the opaque bar being close to the collodion, these pencils could not get underneath. The natural conclusion seems to be, that this extension of the bright bars must have been caused by some molecular reflection taking place in the collodion. This form of irradiation cun easily be distinguished from the irradiation produced by reflection from the back of the plate, as the latter is simply a sort of haze surrounding the bright object, extending some distance from it, and gradualiy fading away, whilst the former extends a very short distance and has a well-marked outline, though not so sharp as those parts of the image where there is no irradiation. The irradiation produced by reflection from the back of the plate, and some forms of irradiation due to the imperfections of the lens, though fatal to ar.istic photography, yet do not interfere much with its scientific value, as they do not affect the accuracy of outline, though they do affect the clearnesss of the photograph. Molecular irradiation, on the other hand, whilst it scarcely affects artistic photography, is fatal to scientific accuracy. The manner of preventing this latter form of irradiation has baen already pointed out, namely, by reducing the intensity of the light falling on the sensitive surface to only that necessary to produce a distinct impression. In artistic photography this is almost never possible on account of the different amount of light on the different parts of the subject, while for scientific purposes this may almost always be done. The imperfections of the image due to the lens seem to be as various as the forms of lenses; one lens used in the experiments gave a curious double hazy-image of the bright object. When the image is near the centre of the "field" the double image fits over the true image, producing an effect somewhat similar to, and was at first mistaken for the effect of reflection from the back of the plate. At first this double image was somewhat puzzling, as it always made its appearance even when opaque plates were used. The two imagas were, however, afterwards separated by bringing the true im.xge near the outside of the "field," whan the true image and its doubla were photographed alongside of each other.

The following simple experiment illlustratez this molecular form of irradiation, and shows how much the definition of the image depends on the nature of the surface which recaives it. Take a camera obscura and throw the image on some tran;lucent substance such as opal glass; paint a small part of the glass with some op zque white suostance; bring into the "fieid" some brilliantly illuminated subject, such as branches of trees against the sky; examine the imige from the lens side of the glass, when it will be found that the image ovec the opal glass is hazy and indistinct, whilst the part of the image on the paint shines out brilliant and sharp.

Darroch, Falkirk, N.B. June 16

\section{Lakes with two Outfalls-A Caution}

LLYN CREIGENEN (the larger of the two lakes of that name), situated about five miles S.W. by W. of Dolgelly, has apparensly two natural outlets-one at the east, the other at the west end of the lake; both streams altimately fall into the estuary of the Mawddach. The two outlets are on nearly the same level, the one at the east end being perhaps a trifle higher than that at the west end. The whole of the waste water at present passes through the western vutlet in consequence of an artificial dam of turf having been made across the eastern channel. There are no indications on the ground which would lead anyone to suspect that either of the outlets had been artificially formed; the general contour of the surrounding country would rather favour the contrary view.

I wa:, however, informed last week by a man who had lived eighteen years in the district that he had been told that originally the only outlet was that at the west en.1 of the Liyn, and that the other outlet had been made many years ago for the purpose of getting a better supply of water to some mills which then existed, but which do not now exist, on the stream to the east of the lake. If this story prove to be correct it shows how im. portant it is to make full inquiries before stating positively that any lake has two natural outfalls.

From the ordnance map one would imagine that two streams issued from Llyn Areaig (five miles W.N.W. of Bala), but the one shown as starting from the extreme north end of the lake has no existence in fact.

Chester, June 3

$$
\text { FERDINAND STOLICZKA, PH.D. }
$$

A BRIEF telegram from India, which arrived just in time for notice in last week's NATURE (vol. x. p. I72), announced the death on the Igth ult, at Snayok, between the Karakorum Pass and Leh in Ladak, of Ferdinand Stoliczka, Palaontologist to the Geological Survey of India, who was returning from Kashgar and Yarkund with the other members of Mr. Forsyth's mission.

Thus has passed away, at the early age of thirty-six, a naturalist who, if his life had been spared, would certainly have attained a very high position amongst the leaders of science. Few men have accomplished an equal amount of work in the same brief space of time. A glaace at the Journal and Proceedings of the Bengal Asiatic Society, and the publications of the Geological Survey of India, especially the "Palæoatologia Indica," will show the wonderful variety of subjects tre ated by Dr. Stoliczka. In the course of the last ten years, besides geological memoirs on parts of the Western Himalayas and Thibet, he has published numerous papers on Indian mammals, birds, reptiles, amphibia, mollusca, bryozoa, arachnida, coleoptera, and actinozoa; and these papers are no lists of names or mere descriptions of new species, but they abound with accounts of the life history of the different animals, details of their anatomy, and remarks on clasification, and show that their author was as goxd an observer in the field as he was patient and accurate in the cabinet. His greatest work is undoubtedly his account of the fossil fauna discovered in the Cretaceous rocks of Southern India, in which he proposed the most complete 
general classification of Gasteropoda and Pelecypoda (Lamellibranchiata), including both fossil and recent forms, which has hitherto been attempted. This classification was largely supplemented by original anatomical research, and it has been adopted in one, at least-we believe in two- of the principal museums in Germany.

Dr. Stoliczka was born in Moravia in May 1838 . After completing his university course he joined, whilst quite young, the Imperial Geological Institute of Austria, where he soon distinguished himself by his palæontological work, and became especially known for researches amongst the Bryozoa, fossil and recent. The collection of specimens belonging to that class obtained by the Novara expedition was intrusted to him for description. Amongst his principal early contributions to palæontology were papers on the fossil fauna of the Hierlatz and Gosau beds.

In 1862 he joined the Geological Survey of India, and at once commenced the study of the magnificent series of Cretaceous fossils obtained by Messrs. H. F. Blanford, C. Oldham, and the other officers of the Survey engaged in the Madras Presidency. The descriptions of these fossils have only recently been completed, and extend altogether to about $\mathrm{I}, 500$ quarto pages illustrated by $\mathrm{I} 78$ plates. There can be no doubt of the rank of this work ; it is one of the most complete monographs ever published of any fossil fauna whatever. The numerous duties connected with the post of Palæontologist to the Survey occupied so much of Dr. Stoliczka's time that he was only able to devote a few months in three different years to field-work. To this field-work we owe valuable reports on the western Himalayas, Thibet, and Kachh, the last not yet published. In the year I 868 he accepted the honorary secretaryship of the Asiatic Society, and during the five years he held the post he raised the natural history portion of the Society's journal to a position it had never approached before, this improvement being due no less to his own contributions than to the aid he was always ready to afford to all engaged in zoological inquiry.

When, last year, a mission was despatched by the Indian Government to Yarkund and Kashgar, Dr. Sto liczka was selected to accompany it as naturalist and geologist. It would have been impossible to have found anyone more competent for the post, but many of his friends knew the risk he ran, and he was well aware of it himself, for his health had been seriously affected by exposure in former years in the higher regions of the Himalayas, and he needed rest and a change to Europe. His lite has been a sacrifice to the study to which he had devoted it. He was seriously ill at one time when crossing the high passes on his way to Yarkund, but recovered, and his letters from Kashgar gave glowing accounts of his discoveries, and now when returning loaded with the spoils and notes of nearly a year's research in one of the least-known parts of Central Asia he has fallen, just as his friends were in hopes of welcoming him back amongst them. This is not the place to speak of his many amiable qualities, but few men were more widely known in India or more universally beloved and esteemed, and the gap he has left in the little band of Indian naturalists and geologists, as well as amongst the far wider circle of his private friends, will be long unfilled.

W. T. B.

OBSERVATORIES IN THE UNITED STATES

$\mathrm{NE}$ of the most salient points in the scientific progress of America is undoubtedly the marvellous multiplication of first-class observatories during recent years. The genius of her people, the skill of her artists, and the wise liberality of states and individuals have combined to bring about a state of things which those interested in Astronomy in any country on this side of the Atlantic may regard with the intensest envy. Undoubtedly our own observatories are already distanced in everything except "activity. In number, "instrumental equipment, breadth of design, the American institutions are unsur. passed; and although the Americans themselves say they want men with such world-wide names as Peirce, Winlock, Newcomb, Young, Peters, and many others that we might mention, who know no resting on old laurels, it is difficult for an Englishman to acknowledge that the idea is well founded.

A very interesting and well-illustrated article on United States Observatories appears in a recent number of Harper's Montizly. Some of the illustrations, which we are enabled to give by the courtesy of the Editor, give a good idea of the scientific wealth to which we refer, and of the progress that has been made, for while little more than thirty years ago it could not be said that there was one astronomical observatory in the United States, to-day it is safe to place the number of all classes, public and private, bejond fifty.

Cincinnati Observatory.-One of the most strentious advocates for the establishment of public observatories in the United States was John Quincy Adams, who had made astronomy a favourite pursuit. He had very just conceptions of what ought to be the character and aims of a true observatory. It must steadily labour for discovery. It must be fully equipped for this, and be provided with a personnel who could give their whole energies to that series of observations, running through many years, which alone can secure valuable additions to astronomical knowledge and insure its benefits to men. For the establishment of such an institution he had made his well-known appeal to Congress in 1825 . He was ridiculed; but he remained as strenuous an advocate as ever for the establishment of observatories of the first class both at Washington and at Cambridge. In the very year before this address at Cincinnati he had urged, in his place in Congress, the perpetual appropriation of the whole interest of the then unappropriated Smithsonian fund for an observatory for the people.

"The express object of observatories," said he, "is the increase of knowledge by new discovery. It is to the successive discoveries of persevering astronomical observations through a period of fifty centuries that we are indebted for a permanent standard of time and for the measurement of space."

The year 1843 was, however, an era in the history of United States observatories, and Cincinnati was their birthplace. Her institution and those of Cambridge and Washington sprang up, and the enthusiasm of the era started others, whose equipment has been secured largely by their success.

As early as I 805 , Cincinnati may be said to have had a practical working observatory. In that year the first Surveyor-General of the United States, Colonel Jared Mansfield, received, after a delay of at least three years in their construction and transportation from London, astronomical instruments ordered by Albert Gallatin, Secretary of the Treasury, and paid for by President Jefferson out of his own contingent fund, "since no appropriation for them had been made by law." The instruments, which were said to have been excellent of their kind, were a 3. foot reflecting telescope, a 30-inch portable transit in. strument, and an astronomical pendulum clock. Years afterward, they were placed in the philosophical department of the Military Academy at West Point. In the house of the Surveyor-General, at Cincinnati, they were used in making numerous and interesting astronomical observations. The orbit of the comet of 1807 was calculated, eclipses of different kinds were observed, the longitude of the observatory determined, and other observations of importance made from 1807 to 1813 , all of them outside of the usual duties of the mere surveyor.

Our next date is at the end of the lapse of forty years. We are brought then to the marked era in astronomical interest already referred to, and to the labours of those 